\title{
Productivity and Profitability of Summer Sunflower (Helianthus annuus L.) Influenced by Integrated Nutrient Management
}

\author{
A. Mahapatra*, B. Gouda and D. Patel \\ Odisha University of Agriculture and Technology, Bhubaneswar -751003, Odisha, India \\ *Corresponding author
}

\section{A B S T R A C T}

\section{Keywords}

Sunflower, STBFR, FYM, RDF, Boron, Ray floret stage and Nutrient management

Article Info

Accepted:

17 June 2020

Available Online:

10 July 2020
A field experiment was conducted at College of Agriculture, Odisha University of Agriculture and Technology, Bhubaneswar on sandy loam soils during summer season of 2018-19 with an objective of evaluating nutrient management for enhancing sunflower productivity (Helianthus annuus L.) under eastern Indian conditions. The experiment was laid out in a randomized block design with three replications. There were twelve treatment combinations viz., Control, RDF (60:80:60 kg N: $\left.\mathrm{P}_{2} \mathrm{O}_{5}: \mathrm{K}_{2} \mathrm{O} / \mathrm{ha}\right), \mathrm{RDF}+\mathrm{S} @ 40$ kg/ha,RDF + B @ 0.02\%,RDF + S@ 40 kg/ha + B @ 0.02\%,STBFR (60:100:60 kg N: P2O5: K2O/ha+S@40 kg/ha+B@0.02\%), FYM@5t/ha,RDF+FYM @ 5 t/ha, $\mathrm{RDF}+\mathrm{FYM} @ 5 \mathrm{t} / \mathrm{ha}+\mathrm{S} @ 40 \mathrm{~kg} / \mathrm{ha}, \mathrm{RDF}+\mathrm{FYM} @ 5 \mathrm{t} / \mathrm{ha}+\mathrm{B} @ 0.02 \%, \mathrm{RDF}+$ FYM @ 5 t/ha + S@40 kg/ha + B @ 0.02\%, STBFR+FYM @ 5 t/ha. The results of the study indicated that integrated nutrient management exhibited significant effect on growth, seed and oil yield of sunflower. Application of STBFR + FYM @ 5 t/ha recorded significantly highest growth parameters, seed $(2.59 \mathrm{t} / \mathrm{ha})$ and oil yield(1114 kg/ha) of sunflower which remained at par with RDF+FYM @ 5 t/ha + S@40 kg/ha + B @ $0.02 \%$.

\section{Introduction}

Sunflower is one of the most important high quality oilseed crop which is widely cultivated in different parts of the world. It ranks third in production next to soybean and groundnut. Sunflower oil is generally considered as a premium oil and fetches premium value in the market because of its light colour and high level of poly unsaturated fatty acids (PUFA), anti-cholesterol property with high level of linoleic acid and absence of linolenic acid, which helps in washing out cholesterol deposition in the coronary arteries of the heart and good for heart patient. But sunflower productivity is reduced due to rainfed or partially irrigated conditions, improper availability of hybrids and high yielding seeds suitable for different agroclimatic regions, improper nutrient management, bird attack, and major pests and diseases. Continuous use of high level of chemical fertilizers is adversely affecting the sustainability of agricultural production and causing environmental pollution. Therefore in the coming decades, integrated nutrient management will play a significant role in improving the crop yield as well as in 
designing sustainable agriculture systems. In this context, an attempt has been made to augment summer sunflower cultivation by incorporating a plethora of nutrient management regimes with recommended fertilise dose.

\section{Materials and Methods}

The experiment was conducted at Agronomy Main Research Farm, OUAT, Bhubaneswar during summer, 2019. The station is geographically located at $20^{\circ} 12^{\prime} \mathrm{N}$ latitude and $85^{\circ} 52^{\prime}$ E longitude respectively with an altitude of $25.9 \mathrm{~m}$ above mean sea level. The soil of experimental field was sandy loam having $295 \mathrm{~kg} / \mathrm{ha}$ available $\mathrm{N}, 10.65 \mathrm{~kg} / \mathrm{ha}$ available $\mathrm{P}, 147.84 \mathrm{~kg} / \mathrm{ha}$ exchangeable $\mathrm{K}$ and $0.62 \%$ organic carbon. The $\mathrm{pH}$ of the soil was 5.3. The experiment was laid out in a randomized block design, replicated thrice with twelve treatments: Control, RDF (60:80:60 kg N: $\left.\mathrm{P}_{2} \mathrm{O}_{5}: \mathrm{K}_{2} \mathrm{O} / \mathrm{ha}\right), \mathrm{RDF}+\mathrm{S} @$ $40 \mathrm{~kg} / \mathrm{ha}, \mathrm{RDF}+\mathrm{B} @ 0.02 \%$ at ray floret opening stage, RDF + S @ 40 kg/ha + B @ $0.02 \%$ (at ray floret opening stage), soil test based fertiliser recommendation (STBFR 60:100:60 kg N: $\left.\mathrm{P}_{2} \mathrm{O}_{5}: \mathrm{K}_{2} \mathrm{O} / \mathrm{ha}\right)+\mathrm{S} @ 40$ kg/ha+B@0.02\%, FYM @ 5 t/ha, RDF + FYM @ 5 t/ha, RDF + FYM @ 5 t/ha + S @ $40 \mathrm{~kg} / \mathrm{ha}, \mathrm{RDF}+\mathrm{FYM} @ 5 \mathrm{t} / \mathrm{ha}+\mathrm{B}$ @ $0.02 \%, \mathrm{RDF}+\mathrm{FYM} @ 5 \mathrm{t} / \mathrm{ha}+\mathrm{S} @ 40 \mathrm{~kg} / \mathrm{ha}$ +B@0.02\%,STBFR+FYM @ 5 t/ha. Plant geometry of $60 \mathrm{~cm} \times 30 \mathrm{~cm}$ was maintained with sunflower KBSH-53 as the test hybrid. Well decomposed FYM, full dose of phosphorus, potassium, sulphur and half of nitrogen was applied as basal dose while remaining nitrogen was applied in two equal split applications at knee-high stage and at 5055 DAS. The source of N, P and K, S and B were Urea, Diammonium phosphate, Muriate of potash, Gypsum, and Borax respectively. All the cultural operations were performed as per the standard package of practices of sunflower. Observations on morphological parameters were recorded from ten randomly selected plants while yield was recorded on net plot basis. The raw data was subjected to appropriate statistical procedure as suggested by Gomez and Gomez (1984). The gross plot size was $5.5 \mathrm{~m} \times 3.2 \mathrm{~m}\left(17.6 \mathrm{~m}^{2}\right)$. Preemergence application of pendimethalin @ $1.0 \mathrm{~kg}$ a.i./ha was done uniformly. Two hand weedings were done at 20 and 40 DAS. During the experimental period, a total of five irrigations were given uniformly to all plots and irrigation was ceased 25 days before harvesting. The crop was kept free from pests and diseases by taking up the need-based plant protection measures. The crop was harvested when back of the head (capitulum) turned to lemon yellow colour.

\section{Results and Discussion}

\section{Growth parameters}

STBFR + FYM @ 5 t/ha has registered tall plants $(207.3 \mathrm{~cm})$ at harvest and was at par with RDF + FYM @ 5 t/ha + S @ 40 kg/ha + B @ $0.02 \%$. An increase in plant height might be attributed to positive effect of FYM, soil test based fertilizer application, along with availability of secondary nutrient Sulphur and micronutrient Boron which supplied the required nutrients at an optimum rate at all growth stages. The results are in conformity with the findings of by Rasool et al., (2013).

The number of leaves per plant and LAI was significantly different with nutrient management options. Highest number of leaves per plant (33.1) and LAI (3.39) was recorded with STBFR + FYM @ 5 t/ha at 75 DAS which remained at par with RDF + FYM@ 5 t/ha + S@ 90 kg/ha + B@0.02\% with 31.6 number of leaves per plant and LAI of 3.35. The minimum leaf area index was noticed in control. Different nutrient management caused significant variation in the dry matter accumulation. The maximum 
dry matter accumulation per plant was observed with STBFR + FYM @ 5 t/ha at harvest $(145.69 \mathrm{~g})$ which remained at par with RDF+FYM@5 t/ha + S@40 kg/ha+B@ $0.02 \%$. Farmyard manure (FYM) significantly improved the growth parameters of sunflower. Incorporation of FYM at 5 t/ha along with balanced application of NPK improved the growth parameters over no application. This might be due to improvement in soil physical, chemical and biological properties, provision of plant growth promoting substances such as auxin, amino acids and vitamins produced during decaying which promote the plant growth, enhanced nutrition status due to addition of organic manure and the release of micronutrients.

This corroborates the findings of Ahmad and Jabeen (2009). Sulphur plays a major role in regulating the metabolic and enzymatic processes including photosynthesis and respiration as reported by Intodia and Tomar (1997). Boron plays a major role in the plant cell wall structure and transport of water and nutrients and organic compounds for new growth and cell wall stability (Havlin et al., 2010). Application of balanced NPK based on soil test values along with FYM, sulphur and boron exerted positive influence on all the growth parameters of sunflower. The CGR increased up to 45-60 DAS and declined thereafter up to harvest irrespective of treatments imposed. The maximum CGR was observed with STBFR + FYM @ 5 t/ha at 4560 DAS $\left(17.023 \mathrm{~g} / \mathrm{day} / \mathrm{m}^{2}\right)$ which remained at par with RDF + FYM @ 5 t/ha + S @ 40 $\mathrm{kg} / \mathrm{ha}+\mathrm{B} @ 0.02 \%$ with CGR of 16.603 $\mathrm{g} / \mathrm{day} / \mathrm{m}^{2}$. While, the minimum CGR at all the crop growth stages were observed with control. STBFR + FYM @ 5 t/ha recorded highest CGR due to better crop growth and dry matter accumulation. These finding were also noticed by Chavan (1973) and Sharma (1994).

\section{Yield}

Highest number of seeds per head was due to influence of $\mathrm{B}$ on flowering, pollen germination, fertilization, cell division and water relationship. The filled seeds/head increased with B application, as it increased the pollen producing capacity and pollen grain viability. Appropriate dose of boron affect positively the inner tissues of plant which leads to head seed filling due to better development of pollen tubes.

These finding were supported by Pavani et al., (2012) and Rasool et al., (2013). Effect of nutrient management on 1000 seed weight was found non- significant. It is a genotypic character so there was no significant variation due to different nutrient management. Significantly highest seed yield (2.59 t/ha) and oil yield $(1114 \mathrm{~kg} / \mathrm{ha})$ was recorded with STBFR + FYM@5t/ha which remained at par with RDF + FYM @ 5 t/ha + S@40 kg/ha + B@ 0.02\% (2.37 t/ha and 1000 kg/ha respectively). STBFR with FYM directly increased crop yields either by acceleration of respiratory process, by increasing cell permeability, by hormone growth action or by combination of all the processes viz., release of nutrients, increasing availability of nutrients and improving soil physical, chemical and biological properties. The beneficial effect of FYM on sunflower yield is well documented by Sheoran et al., (2017). Inclusion of organic manure might have enhanced soil microbial biomass carbon than those receiving chemical fertilizers (Mohammadi et al., 2012) to enhance sunflower yield. Production of photosynthates and their translocation to sink mainly depends upon availability of mineral nutrients in the soil. Most of the pathways are dependent on enzyme and co-enzymes, which are synthesized by these mineral nutrients such as sulphur, boron, major nutrients (NPK) and FYM. Better translocation of photosynthates 
from source to sink enabled better growth and yield attributing parameters and finally the seed yield of crop. This corroborates the findings of Rasool et al., (2013). Highest oil yield might be due to better synthesis of sulphur containing amino acids and fatty acids synthesis (conversion of Acetyl CO-A to Melonyl CO- A) resulting from increased activity of thiokinase enzyme which depends upon sulphur supply. Similar results were reported by Rasool et al., (2013). Higher B application increased the oil content due to better pollination and seed set leading to formation of protein and oil synthesis thereafter (Tahir et al., 2014).

\section{Nutrient uptake}

Statistically higher N, P, K, S and B uptake (119.79 kg/ha, $23.87 \mathrm{~kg} / \mathrm{h}$ and $106.36 \mathrm{~kg} / \mathrm{ha}$, $22.99 \mathrm{~kg} / \mathrm{ha}$ and $479.63 \mathrm{~g} / \mathrm{ha}$ respectively) was recorded with STBFR + FYM @ 5 t/ha which remained at par with RDF+FYM @ 5 t/ha+S@40 kg/ha + B @ 0.02\%. Increased uptake was due to application of higher doses of nutrients along with secondary nutrient $S$, micronutrient $\mathrm{B}$ and orgnic manure, FYM which resulted in vigorous growth and high photosynthetic rate leading to better uptake throughout the crop growth period. This result is in conformity with the findings of Debina et al., (2016) and Kalaiyarasan et al., (2017).

Table.1 Growth of sunflower as influenced by nutrient management

\begin{tabular}{|c|c|c|c|c|c|}
\hline Treatment & $\begin{array}{l}\text { Plant } \\
\text { height } \\
\text { (cm) at } \\
\text { harvest }\end{array}$ & $\begin{array}{l}\text { Dry } \\
\text { matter at } \\
\text { harvest } \\
\text { (g/plant) }\end{array}$ & $\begin{array}{l}\text { No of } \\
\text { functional } \\
\text { leaves } \\
\text { plant }^{-1} \\
\text { (75 DAS) }\end{array}$ & $\begin{array}{l}\text { Leaf area } \\
\text { index } \\
\text { (LAI) } \\
\text { (75 DAS) }\end{array}$ & $\begin{array}{l}\text { Crop } \\
\text { growth rate } \\
(\text { g/day/m²) } \\
(45-60 \text { DAS })\end{array}$ \\
\hline $\mathrm{T}_{1}$ - Control & 161.0 & 100.71 & 20.20 & 3.10 & 10.460 \\
\hline $\begin{array}{l}\mathrm{T}_{2^{-}} \mathrm{RDF}\left(60: 80: 60 \mathrm{~kg} \mathrm{~N}: \mathrm{P}_{2} \mathrm{O}_{5}: \mathrm{K}_{2} \mathrm{O}\right. \\
\text { /ha) }\end{array}$ & 178.0 & 112.29 & 27.98 & 3.16 & 11.823 \\
\hline $\mathrm{T}_{3^{-}} \mathrm{RDF}+\mathrm{S} @ 40 \mathrm{~kg} / \mathrm{ha}$ & 181.2 & 115.87 & 28.13 & 3.18 & 12.557 \\
\hline $\mathrm{T}_{4} \mathrm{RDF}+\mathrm{B} @ 0.02 \%$ & 184.6 & 118.17 & 28.80 & 3.21 & 12.887 \\
\hline $\begin{array}{l}\mathrm{T}_{5} \mathrm{RDF}+\mathrm{S} @ 40 \mathrm{~kg} / \mathrm{ha}+\mathrm{B} @ \\
0.02 \%\end{array}$ & 188.3 & 127.79 & 30.17 & 3.27 & 14.980 \\
\hline $\begin{array}{l}\mathrm{T}_{6}-\mathrm{STBFR}\left(60: 100: 60 \mathrm{~kg} \mathrm{~N}: \mathrm{P}_{2} \mathrm{O}_{5}:\right. \\
\mathrm{K}_{2} \mathrm{O} / \mathrm{ha}+\mathrm{S} @ 40 \mathrm{~kg} / \mathrm{ha}+\mathrm{B} @ \\
0.02 \%)\end{array}$ & 198.0 & 137.55 & 31.23 & 3.32 & 15.863 \\
\hline T ${ }_{7}$ FYM @ 5 t/ha & 169.4 & 106.48 & 24.27 & 3.12 & 10.703 \\
\hline $\mathrm{T}_{8}-\mathrm{RDF}+\mathrm{FYM} @ 5 \mathrm{t} / \mathrm{ha}$ & 187.7 & 122.10 & 29.44 & 3.24 & 13.670 \\
\hline $\begin{array}{l}\mathrm{T}_{9^{-}} \mathrm{RDF}+\mathrm{FYM} @ 5 \mathrm{t} / \mathrm{ha}+\mathrm{S} @ 40 \\
\mathrm{~kg} / \mathrm{ha}\end{array}$ & 194.3 & 131.08 & 30.47 & 3.28 & 15.527 \\
\hline $\begin{array}{l}\mathrm{T}_{10^{-}} \mathrm{RDF}+\mathrm{FYM} @ 5 \mathrm{t} / \mathrm{ha}+\mathrm{B} @ \\
0.02 \%\end{array}$ & 196.2 & 133.11 & 31.03 & 3.30 & 15.620 \\
\hline $\begin{array}{l}\mathrm{T}_{11}-\mathrm{RDF}+\mathrm{FYM} @ 5 \mathrm{t} / \mathrm{ha}+\mathrm{S} @ 40 \\
\mathrm{~kg} / \mathrm{ha}+\mathrm{B} @ 0.02 \%\end{array}$ & 202.6 & 142.12 & 31.62 & 3.35 & 16.603 \\
\hline $\mathrm{T}_{12^{-}}$STBFR + FYM @ $5 \mathrm{t} / \mathrm{ha}$ & 207.3 & 145.69 & 33.11 & 3.39 & 17.023 \\
\hline $\mathrm{SEm} \pm$ & 2.66 & 1.66 & 0.62 & 0.02 & 0.2644 \\
\hline$C D(p=0.05)$ & 7.8 & 4.96 & 1.82 & 0.07 & 0.785 \\
\hline
\end{tabular}


Table.2 Yield attributing characters and yield of sunflower as influenced by different nutrient management

\begin{tabular}{|c|c|c|c|c|c|c|c|c|}
\hline \multicolumn{2}{|r|}{ Treatments } & \multirow{2}{*}{$\begin{array}{c}\begin{array}{c}\text { Head dia. } \\
\text { (cm) }\end{array} \\
11.94\end{array}$} & \multirow{2}{*}{$\begin{array}{c}\begin{array}{c}\text { Head wt. } \\
\text { (g) }\end{array} \\
54.29\end{array}$} & \multirow{2}{*}{$\begin{array}{c}\begin{array}{c}\text { Total } \\
\text { number } \\
\text { of seeds } \\
\text { per head }\end{array} \\
656.6\end{array}$} & \multirow{2}{*}{$\begin{array}{c}\begin{array}{c}\text { Number of } \\
\text { filled seeds per } \\
\text { head }\end{array} \\
487.6\end{array}$} & \multirow{2}{*}{$\begin{array}{c}1000 \text { seed } \\
\text { weight (g) }\end{array}$} & \multirow{2}{*}{$\begin{array}{c}\begin{array}{c}\text { Seed yield } \\
\text { (t/ha) }\end{array} \\
0.84\end{array}$} & \multirow{2}{*}{$\begin{array}{c}\begin{array}{r}\text { Oil yield } \\
\text { (kg/ha) }\end{array} \\
297\end{array}$} \\
\hline T1 & Control & & & & & & & \\
\hline $\mathbf{T} 2$ & $\begin{array}{l}\text { RDF (60:80:60 kg N: } \mathrm{P}_{2} \mathrm{O}_{5}: \mathrm{K}_{2} \mathrm{O} \\
\text { /ha) }\end{array}$ & 15.10 & 68.58 & 938.1 & 779.7 & 47.29 & 1.52 & 592 \\
\hline T3 & RDF+S @ 40 kg/ha & 15.59 & 70.84 & 996.8 & 840.4 & 47.32 & 1.69 & 679 \\
\hline T4 & RDF+B@0.02\% & 15.93 & 73.37 & 1042.4 & 901.8 & 48.38 & 1.72 & 684 \\
\hline T5 & RDF+S@ $@ 40$ kg/ha+B @ 0.02\% & 16.89 & 80.72 & 1168.7 & 1029.4 & 49.48 & 1.99 & 819 \\
\hline T6 & $\begin{array}{l}\text { STBFR (60:100:60 kg N: P2O5: } \\
\mathrm{K} 2 \mathrm{O} / \mathrm{ha}+\mathrm{S} @ 40 \mathrm{~kg} / \mathrm{ha}+\mathrm{B} @ \\
0.02 \%)\end{array}$ & 18.13 & 90.54 & 1198.5 & 1062.0 & 49.50 & 2.18 & 917 \\
\hline T7 & FYM@5 t/ha & 12.58 & 62.86 & 770.5 & 611.7 & 45.31 & 1.24 & 448 \\
\hline T8 & RDF+FYM@ 5 t/ha & 16.36 & 77.28 & 1063.4 & 913.9 & 47.81 & 1.83 & 738 \\
\hline T9 & $\begin{array}{l}\text { RDF + FYM @ } 5 \text { t/ha + S @ } 40 \\
\text { gg/ha }\end{array}$ & 17.30 & 83.18 & 1139.3 & 1001.2 & 47.97 & 2.01 & 838 \\
\hline T10 & RDF+FYM@5t/ha+B@ $0.02 \%$ & 17.92 & 86.41 & 1193.2 & 1058.8 & 48.70 & 2.09 & 865 \\
\hline T11 & $\begin{array}{l}\mathrm{RDF}+\mathrm{FYM} @ 5 \mathrm{t} / \mathrm{ha}+\mathrm{S} @ 40 \\
\mathrm{~kg} / \mathrm{ha}+ \\
\mathrm{B} @ 0.02 \%\end{array}$ & 18.36 & 94.82 & 1298.2 & 1179.4 & 49.50 & 2.37 & 1000 \\
\hline T12 & STBFR + FYM@ 5 t/ha & 18.68 & 97.76 & 1313.1 & 1201.7 & 49.51 & 2.59 & 1114 \\
\hline \multicolumn{2}{|c|}{ SEm \pm} & 0.150 & 1.798 & 19.10 & 18.15 & 1.633 & 0.11 & 44.9 \\
\hline \multicolumn{2}{|c|}{ CD $(P=0.05)$} & 0.43 & 5.27 & 57.1 & 54.2 & NS & 0.33 & 132.0 \\
\hline
\end{tabular}

Table.3 Nutrient uptake of sunflower as influenced by different nutrient management

\begin{tabular}{|c|c|c|c|c|c|c|}
\hline \multicolumn{2}{|c|}{ Treatments } & \multirow{2}{*}{$\begin{array}{c}\begin{array}{c}\text { Nitrogen } \\
\text { (kg/ha) }\end{array} \\
41.40\end{array}$} & \multirow{2}{*}{$\begin{array}{l}\text { Phosphorus } \\
\text { (kg/ha) } \\
7.39\end{array}$} & \multirow{2}{*}{$\begin{array}{c}\begin{array}{c}\text { Potassium } \\
\text { (kg/ha) }\end{array} \\
37.93\end{array}$} & \multirow{2}{*}{$\begin{array}{c}\text { Sulphur } \\
\text { (kg/ha }\end{array}$} & \multirow{2}{*}{$\begin{array}{c}\begin{array}{c}\text { Boron } \\
(\mathrm{g} / \mathrm{ha})\end{array} \\
149.90\end{array}$} \\
\hline T1 & Control & & & & & \\
\hline T2 & $\begin{array}{l}\mathrm{RDF}(60: 80: 60 \mathrm{~kg} \mathrm{~N}: \mathrm{P} 2 \mathrm{O} 5: \mathrm{K} 2 \mathrm{O} \\
\text { /ha) }\end{array}$ & 71.96 & 13.31 & 63.93 & 10.80 & 261.21 \\
\hline T3 & RDF+ S @ 40 kg/ha & 79.38 & 14.85 & 69.95 & 13.41 & 287.92 \\
\hline T4 & RDF+B @ 0.02\% & 80.39 & 15.11 & 70.57 & 13.13 & 309.59 \\
\hline T5 & RDF + S @ 40 kg/ha + B @ 0.02\% & 91.98 & 17.75 & 80.15 & 16.84 & 347.27 \\
\hline T6 & $\begin{array}{l}\text { STBFR (60:100:60 kg N: P2O5: } \\
\text { K2O /ha + S } \\
\text { @ 40 kg/ha + B @ 0.02\%) }\end{array}$ & 100.25 & 19.89 & 88.10 & 18.77 & 387.11 \\
\hline T7 & FYM @ 5 t/ha & 59.59 & 10.84 & 53.64 & 8.70 & 216.74 \\
\hline T8 & RDF+FYM @ 5 t/ha & 86.04 & 16.23 & 76.07 & 15.13 & 320.85 \\
\hline T9 & $\begin{array}{l}\text { RDF+FYM @ } 5 \text { t/ha + S @ } 40 \\
\text { gg/ha }\end{array}$ & 93.50 & 18.24 & 82.18 & 17.30 & 348.89 \\
\hline T10 & $\begin{array}{l}\text { RDF+FYM @ } 5 \text { t/ha + B @ } \\
0.02 \%\end{array}$ & 96.61 & 18.95 & 84.83 & 17.27 & 368.48 \\
\hline T11 & $\begin{array}{l}\text { RDF+FYM @ } 5 \mathrm{t} / \mathrm{ha}+\mathrm{S} @ 40 \\
\mathrm{~kg} / \mathrm{ha}+\mathrm{B} @ 0.02 \%\end{array}$ & 110.65 & 21.83 & 98.74 & 20.99 & 439.52 \\
\hline T12 & STBFR + FYM @ 5 t/ha & 119.79 & 23.87 & 106.36 & 22.99 & 479.63 \\
\hline \multicolumn{2}{|c|}{ SEm \pm} & 3.191 & 1.179 & 2.596 & 0.835 & 15.425 \\
\hline \multicolumn{2}{|c|}{$\mathrm{CD}(\mathrm{P}=\mathbf{0 . 0 5})$} & 9.53 & 3.50 & 7.73 & 2.45 & 46.23 \\
\hline
\end{tabular}


Table.4 Available nitrogen, phosphorus, potassium, sulphur and boron in soil as influenced by different nutrient management after harvest of sunflower crop

\begin{tabular}{|c|c|c|c|c|c|c|}
\hline \multicolumn{2}{|r|}{ Treatments } & \multirow{2}{*}{$\begin{array}{c}\begin{array}{c}\text { Nitrogen } \\
\text { (kg/ha) }\end{array} \\
253.64\end{array}$} & \multirow{2}{*}{$\begin{array}{c}\text { Phosphorus } \\
\text { (kg/ha) }\end{array}$} & \multirow{2}{*}{$\begin{array}{c}\begin{array}{c}\text { Potassium } \\
\text { (kg/ha) }\end{array} \\
109.91\end{array}$} & \multirow{2}{*}{$\begin{array}{r}\begin{array}{r}\text { Sulphur } \\
(\mathbf{k g} / \mathbf{h a})\end{array} \\
15.12\end{array}$} & \multirow{2}{*}{$\begin{array}{r}\begin{array}{c}\text { Boron } \\
(\mathbf{m g} / \mathbf{k g})\end{array} \\
\mathbf{0 . 7 7}\end{array}$} \\
\hline T1 & Control & & & & & \\
\hline T2 & $\begin{array}{l}\text { RDF (60:80:60 kg N: P2O5: } \\
\text { K2O /ha) }\end{array}$ & 283.08 & $\begin{array}{c}12.7 \\
2\end{array}$ & 143.91 & 13.21 & 0.76 \\
\hline T3 & RDF+S@40 kg/ha & 275.66 & $\begin{array}{c}11.9 \\
6\end{array}$ & 137.89 & 21.91 & 0.75 \\
\hline T4 & RDF + B @ 0.02\% & 274.65 & $\begin{array}{c}10.4 \\
6\end{array}$ & 137.27 & 12.66 & 0.80 \\
\hline $\mathbf{T 5}$ & RDF+S@40kg/ha + B@0.02\% & 263.06 & $\begin{array}{c}10.9 \\
3\end{array}$ & 127.69 & 19.21 & 0.78 \\
\hline T6 & $\begin{array}{l}\text { STBFR (60:100:60 kg N: P2O5: } \\
\text { K2O /ha + S @ } 40 \\
\text { kg/ha + B @ 0.02\%) }\end{array}$ & 254.79 & $\begin{array}{c}13.9 \\
2\end{array}$ & 119.74 & 18.50 & 0.77 \\
\hline T7 & FYM@ 5 t/ha & 270.45 & $\begin{array}{c}10.9 \\
6\end{array}$ & 119.20 & 17.82 & 0.79 \\
\hline T8 & RDF+FYM@ 5 t/ha & 307.85 & $\begin{array}{c}13.8 \\
7\end{array}$ & 176.77 & 15.23 & 0.82 \\
\hline T9 & $\begin{array}{l}\text { RDF + FYM @ } 5 \text { t/ha + S @ } 40 \\
\text { kg/ha }\end{array}$ & 299.54 & $\begin{array}{c}12.6 \\
9\end{array}$ & 170.66 & 23.46 & 0.81 \\
\hline $\begin{array}{l}\text { T1 } \\
0\end{array}$ & $\begin{array}{l}\text { RDF+FYM@ @ t/ha + B @ } \\
0.02 \%\end{array}$ & 296.43 & $\begin{array}{c}11.7 \\
4\end{array}$ & 168.01 & 14.10 & 0.86 \\
\hline $\begin{array}{l}\text { T1 } \\
1\end{array}$ & $\begin{array}{l}\mathrm{RDF}+\mathrm{FYM} @ 5 \mathrm{t} / \mathrm{ha}+\mathrm{S} @ 40 \\
\mathrm{~kg} / \mathrm{ha}+\mathrm{B} @ 0.02 \%\end{array}$ & 291.39 & $\begin{array}{c}12.0 \\
2\end{array}$ & 161.10 & 22.55 & 0.85 \\
\hline \multirow[t]{4}{*}{$\begin{array}{l}\text { T1 } \\
2\end{array}$} & STBFR + FYM @ 5 t/ha & 285.25 & $\begin{array}{c}15.5 \\
9\end{array}$ & 153.48 & 21.97 & 0.84 \\
\hline & Initial values & 295.04 & $\begin{array}{c}10.6 \\
5\end{array}$ & 147.84 & 19.00 & 0.80 \\
\hline & SEm \pm & 5.081 & $\begin{array}{c}0.83 \\
1\end{array}$ & 3.228 & 0.509 & 0.015 \\
\hline & CD $(P=0.05)$ & 15.20 & 2.46 & 9.65 & 1.51 & 0.04 \\
\hline
\end{tabular}

\section{Available soil nutrient status}

The highest available $\mathrm{N}$ and $\mathrm{K}$ content of soil $(307.85 \mathrm{~kg} / \mathrm{ha}$ and $176.77 \mathrm{~kg} / \mathrm{ha})$ was recorded with RDF + FYM @ 5 t/ha which remained at par with RDF + FYM @ 5 t/ha + $\mathrm{S} @ 40 \mathrm{~kg} / \mathrm{ha}$ and RDF + FYM @ $5 \mathrm{t} / \mathrm{ha}+\mathrm{B}$ @ $0.02 \%$. Similar results have been reported by Bala and Nath (2015). The highest available phosphorus content of soil (15.59 kg/ha) was recorded with STBFR + FYM @ 5 t/ha which remained at par with STBFR (60:100:60 kg N: P2O5: K2O /ha + S@40 kg/ha+B@0.02\%) and RDF+FYM@5 t/ha. This was due to the effect of applied nutrients, which were applied at a higher rate in these treatments. A significant and positive relation was observed between applied fertilizer levels and their available forms in the soil. These findings are in conformity with Vandhana (2003). The highest available $S$ and B content of soil was recorded with RDF + FYM@ 5 t/ha + S @ $40 \mathrm{~kg} / \mathrm{ha}$ and RDF + FYM @ 5 t/ha + B @ $0.02 \%$ respectively which remained at par with RDF + FYM @ 5 t/ha + S @ 40 kg/ha + B @ 0.02\% and STBFR + FYM@5 t/ha. Those treatments which received higher dosage of sulphur and boron recorded more sulphur and boron content than control which was mainly due to 
residual effect of sulphur and boron. The residual fertility in these treatments was higher as compared to other treatments, because of lower removal of these nutrients by the crop with increasing yield levels.

In conclusion the application of STBFR + FYM @ 5 t/ha resulted in highest growth parameters, yield attributes, yield, oil yield, gross return, net return and $\mathrm{B}: \mathrm{C}$ ratio which remained at par with RDF + FYM @ 5 t/ha + $\mathrm{S} @ 40 \mathrm{~kg} / \mathrm{ha}+\mathrm{B} @ 0.02 \%$. Thus integrated and balanced application of organic and inorganic sources of nutrients (along with micronutrients) is necessary for sustaining summer sunflower yields in sandy loam soils of eastern India.

\section{References}

Ahmad R and Jabeen N 2009. Demonstration of growth improvement in sunflower (Helianthus annuus L.) by the use of organic fertilizers under saline conditions, Pakistan Journal of Botany, 41(3): 1373-1384.

Akbari P, Ghalavand A, ModarresSanavy AM and Alikhani AM 2011. The effect of biofertilizers, nitrogen fertilizer and farmyard manure on grain yield and seed quality of sunflower (Helianthus annus L.), Journal of Agricultural Technology, 7(1): 173-184

Bala M and Nath K. 2015. Maximization of groundnut (Arachis hypogaea L.) yield by nutrient management practices, Journal of Experimental Biology and Agricultural Sciences, 3(3): 214-245.

Chavan, BN. 1973. Growth, nitrogen uptake and yield of three varieties of sunflower as influenced by graded levels of nitrogen and phosphorus and economics of resultant yield curve, M.Sc. (Agri.) thesis, Vasantrao Naik Marathwada Krishi Vidyapeeth, Parbhani

Debina S, Geetha KN and Shankar AG. 2016.
Site-specific nutrient management (SSNM) in groundnut sunflower cropping system, International Journal of Current Research, 8(11): 40838-40842.

Gomez K A and Gomaz A A 1984. Statistical Procedures for Agricultural Research. John Wiley \& Sons, Singapore. Hillel D.1972. Optimizing the Soil Physical Environment Toward Greater Crop Yields. Academic Press, New York.

Havlin JL, Tisdale SL, Nelson WL and Beaton JD 2010. Soil fertility and fertilizers, Prentice Hall, New Delhi, pp. 304-364.

Intodia SK and Tomar OP 1997. Effect of sulphur application on growth and yield of sunflower (Helianthus annuus L.), Indian Journal of Agricultural Sciences, 67(1): 46-47.

Kalaiyarasan C, Jawahar S, Sriramachandrasekharan $\mathrm{MV}$ and Ramesh R. 2017. Effect of Mycorrhizal Inoculation (VAM) and Phosphorus Levels on Yield, Quality, Nutrient Uptake and Post Harvest Nutrient Status of Sunflower, Journal of Agriculture and Ecology Research International, 12(3): 1-7.

Mohammadi K, Heidari G, JavaheriM and NezhadM T K 2012. Soil microbial response to tillage systems and fertilization in a sunflower rhizosphere, Archives of Agronomy and Soil Science, DOI:10.1080/03650340.2012.688197

Pavani S, Bhanu Rekha K, Sudhakar Babu SN and Padmaja G. 2012. Effect of different levels of nitrogen and sulphur on growth and yield of sunflower (Helianthus annuus L.), The Journal of Research Angrau, 40(3): 90-93.

Rasool FU, Hasan B, Jahangir IA, Ali T and Mubarak T 2013. Nutritional yield and economic responses of sunflower (Helianthus annus L.) to integrated 
levels of nitrogen, sulphur and farmyard manure, The Journal of Agricultural Sciences, 8(1): 17-27.

Ravikumar Cand M Ganapathy 2020. Yield maximization through INM in sunflower (Helianthus annuus L.) Journal of Oilseeds Research 37: 149150

Reddy SS, Yadahalli YH, Kumar VK, Kumara O and Naik AH 2002. Effect of fertilizer, gypsum and boron application on yield and economics of sunflower hybrids, Crop Research, 23(3): 450-453.

Sharma RS 1994. Influence of irrigation schedule and fertility levels on yield of sunflower, Indian Journal of Agronomy, 39(3): 496-497.

Sheoran P, VirenderSardana, Sher Singh, SubhashChander, Ashwani Kumar, Anita Mann and Pushp Sharma 2017. Nutrient Management for Sustaining
Productivity of Sunflower-Based Cropping Sequence in Indian Semiarid Regions. Communications in soil science and plant analysis 48(5): 581593

Tahir M, YounasIshaq M, Sheikh AA, Naeem M and Rehman A 2014. Effect of boron on yield and quality of sunflower under agro-ecological conditions of Faisalabad (Pakistan), ScientiaAgriculturae, 7(1): 19-24

Thavaprakash N and Malligawad LH. 2002. Effect of nitrogen and phosphorus levels and ratios on yield and economics of sunflower, Research on Crops, 3: 40-43

Vandhana P. 2003. Response of green chilli (Capsicum annuum L.) to irrigation schedule and fertility levels in Vertisols, M.Sc. (Agri.) thesis, University of Agricultural Sciences, Dharwad.

\section{How to cite this article:}

Mahapatra, A., B. Gouda and Patel, D. 2020. Productivity and Profitability of Summer Sunflower (Helianthus annuиs L.) Influenced by Integrated Nutrient Management. Int.J.Curr.Microbiol.App.Sci. 9(07): 1843-1850. doi: https://doi.org/10.20546/ijcmas.2020.907.212 